\title{
DOI: 10.22620 /agrisci.2021.31.008 \\ HELMINTHS AND HELMINTH COMMUNITIES OF CARASSIUS GIBELIO (BLOCH, 1782) FROM THE PANICHERI RESERVOIR, AEGEAN WATER BASIN, BULGARIA
}

\author{
Diana A. Kirin*, Mariya K. Chunchukova \\ Agricultural University-Plovdiv, Department of Agroecology and Environmental Protection, \\ 12Mendeleev Street, 4000 Plovdiv, BULGARIA \\ *E-mail: dianaatanasovakirin@gmail.com
}

\begin{abstract}
Ecologoparasitological research was done based on the helminths and helminth communities of the Prussian carp (Carassius gibelio (Bloch, 1782)) from the freshwater ecosystem of the Panicheri Reservoir, Aegean Water Basin, Bulgaria. As a result of the examined nine specimens of the Prussian carp, two species of helminths were found: Ligula intestinalis (Linnaeus, 1758), larvae and Pomphorhynchus laevis (Müller, 1776). The dominant structure of the helminth communities was determined. The Panicheri Reservoir is a new habitat in Bulgaria of $P$. laevis and L. intestinalis from $C$. gibelio. C. gibelio is a new host record for L. intestinalis in Bulgaria. The two helminth species are core species for the helminth communities of the examined species of the freshwater fish. P. laevis was distinguished with higher prevalence and mean intensity $(\mathrm{P} \%=33.34 ; \mathrm{MI}=1.34)$ than $\mathrm{L}$. intestinalis $(\mathrm{P} \%=22.23 ; \mathrm{MI}=1.0)$. The circulatory pathways of the helminth flow were traced.
\end{abstract}

Key words: Aegean Water Basin, Carassius gibelio, helminths, helminth communities, reservoir Panicheri.

\section{INTRODUCTION}

The Panicheri Reservoir is an artificial wetland of national importance in Panicheri, Hissarya Municipality, South Central Bulgaria. The Reservoir is located in a mixed deciduous oak and coniferous spruce-pine forest. The Panicheri Reservoir does not fall within the boundaries of protected areas within the meaning of the Protected Areas Act, as well as within the scope of Natura 2000 protected areas, but it is close to the Gerena Protected Site (SG No. 8/2008), located on the land of the village of Panicheri, Municipality of Hissarya, District of Plovdiv, as well as to the Protected Area BG0000444 Pyasachnik River (SG No. 21/2007), declared under the Habitats Directive and Protected Area BG0002010 Pyasachnik Reservoir (SG No. 85/2008), proclaimed under the Birds Directive, etc. The Reservoir was stocked and used for sport fishing. Freshwater fish parasites are characterised by complex developmental cycles. The parasitic communities formed by them are closely related to the conditions in the habitats, to the nutritional relationships between the free-living organisms and thus reflect the biodiversity and the condition of the respective habitats. The parasite species themselves are referred to as the hidden biodiversity of the European Freshwater System (Selbach et al., 2020). Studies on parasites and parasitic communities of $\mathrm{C}$. gibelio have been performed by relatively few authors (Cakis et al., 2001; Djikanovic et al., 2011; Roohi et al., 2014; Kucher et al., 2019; Innal et al., 2020, etc.). These studies are few for the territory of Bulgaria (Margaritov, 1966; Kakacheva-Avramova, 1977; Kakacheva, Margaritov, Grupcheva, 1978; Grupcheva, Nedeva, 1999; Shukerova, 2005; Shukerova, 2010; Atanasov, 2012; Chunchukova, Kirin, 2021, etc.). The study presents first results for the Panicheri Dam for the helminths and helminth communities of $C$. gibelio. 


\section{MATERIALS AND METHODS}

In 2019, nine specimens of the Prussian carp (Carassius gibelio (Bloch, 1782)) from the Panicheri Reservoir, Aegean Water Basin, Bulgaria, were examined for helminths. The fish were caught by angling. The scientific name of the fish was present, according to Froese \& Pauly (Eds.) (2021). The fish were caught in the Reservoir section with coordinates: $42^{\circ} 29^{\prime} 25.9^{\prime \prime} \mathrm{N}$ and $24^{\circ} 37^{\prime} 5.7^{\prime \prime} \mathrm{E}$; $336 \mathrm{~m}$ altitude, located about $2 \mathrm{~km}$ far away from the village Panicheri and about $17 \mathrm{~km}$ from the town of Hisarya, South Central Bulgaria. The helminthological studies were carried out according to Zashev \& Margaritov (1966); Bauer (Ed.) (1987); Petrochenko (1956). The helminth specimens were fixed in $70 \%$ of ethyl alcohol. The species diversity was determined on durable microscope slides carried out by Georgiev, Biserkov \& Genov and on temporary slides carried out by Petrochenko (1956) with glycerin. Two levels were analysed for the helminth community structure: on the level of component community (prevalence $(\mathrm{P} \%)$; mean intensity (MI) for the determined species) and on the level of infracommunity (total number of fish species; total and mean number of fish specimens; Brillouin's diversity index (HB)). In the component community, the found species were divided into core species $(\mathrm{P} \%>20)$, component species $(\mathrm{P} \%>10)$ and accidental species $(\mathrm{P} \%<10)$, according to the criteria of Magurran (1988); Bush et al. (1997) and Kennedy (1997). The obtained results were statistically processed using Statistica 10 (StatSoft Inc., 2011) and MS Exel (Microsoft 2010).

\section{RESULTS}

\section{Characteristics of the studied fish species}

The Prussian carp (Carassius gibelio (Bloch, 1782; Cyprinidae) is freshwater, brackish, benthopelagic, potamodromous fish species. The species is widespread on the territory of the Republic of Bulgaria. The Prussian carp is omnivorous species, but in the cold months, it feeds on worms, insects' larvae, even small fish, and in the summer months, mainly on plant food. The fish species is very durable and unpretentious to the quality of the waters it inhabits - withstands minimal amounts of dissolved oxygen, in the range of $0.6-0.5$ $\mathrm{cm} 2.1-1$. The fish inhabits gullies, swamps, corpses and old riverbeds, small dams, gravel pits, the lower sections of slow-moving rivers and large dams. Populations of the species develop cyclically - in about 5-6 years, high intensity of populations of large adult specimens has been established, which are then absent. At low temperatures and especially when freezing shallow water to the bottom, the fish are buried in the mud and fall into anabiosis, which is a biological device for the survival of the populations of the species. A specific way of reproduction distinguishes the Prussian carp by external fertilisation. When fertilising the caviar from the male specimens of the same species, the male or female specimens hatch, and when fertilised from other species, only female Prussian carps are obtained. C. gibelio has Not Evaluated conservation status (IUCN Red List Status, CITES, Convention on the Conservation of Migratory Species of Wild Animals) on the European scale as a native or non-native species (Kottelat \& Freyhof 2007). The species of fish is not protected on the territory of Bulgaria (Golemanski, 2011).

\section{Helminths and helminth community structure}

The subject of ecologoparasitological research is nine specimens of $C$. gibelio. Two types of helminths have been identified in the study: Ligula intestinalis (Linnaeus, 1758) (larvae; Cestoda) and Pomphorhynchus laevis (Müller, 1776) (Acanthocephala). L. intestinalis was found in two specimens of the studied fish and P. laevis - in three specimens of them (Table1). No mixed invasion was 
detected. In four specimens of the Prussian carp, no helminth infestation was detected. $L$. intestinalis is an allochthonous species for parasitic communities of $C$. gibelio. The developmental cycle of $L$. intestinalis is carried out with two groups of intermediate hosts and definitive hosts, fish-eating birds. It has been established that from the egg, which falls into the water, the stage of coracidia develops, which with the food falls into the body cavity of the crustaceans (Crustacea; Copepoda): Cyclops strenuus Fischer, 1851, Acanthocyclops bicuspidatus (Claus, 1857), A. viridis (Jurine, 1820), Eucyclops serrulatus (Fischer, 1851), Diaptomus gracilis Sars, 1902.

Table 1.Biodiversity and ecological indices of the helminth communities of Carassius gibelio from the Panicheri Reservoir

\begin{tabular}{|c|c|c|c|c|}
\hline $\begin{array}{l}\text { Ekological indices } \\
(\mathrm{N}=9) \\
\text { Helminth species }\end{array}$ & $\mathrm{n}$ & $\mathrm{p}$ & $\begin{array}{l}\text { MI } \\
\text { (range) }\end{array}$ & $\mathrm{P} \%$ \\
\hline \multicolumn{5}{|c|}{$\begin{array}{c}\text { Class Cestoda Rudolphi, } 1808 \\
\text { Order Pseudophyllidea Carus, } 1863 \\
\text { Family Diphyllobothriidae Lühe, } 1910 \\
\text { Genus LigulaBloch, } 1782\end{array}$} \\
\hline $\begin{array}{l}\text { Ligula intestinalis } \\
\text { (Linnaeus, 1758), } \\
\text { larvae }\end{array}$ & & 2 & $\begin{array}{l}1,0 \\
(1)\end{array}$ & 22,23 \\
\hline \multicolumn{5}{|c|}{$\begin{array}{l}\text { Class Acanthocephala Rudolphi, } 1808 \\
\text { Order Echinorhynchida Southwell et Macfie, } 1925 \\
\text { Family Pomphorhynchidae Yamagiti, } 1939 \\
\text { GenusPomphorhynchus, Monticelli, } 1905\end{array}$} \\
\hline $\begin{array}{l}\text { Pomphorhynchus } \\
\text { laevis } \\
\text { (Müller, 1776) }\end{array}$ & 3 & 4 & \begin{tabular}{|l|}
1,34 \\
$(1-2)$
\end{tabular} & 33,34 \\
\hline
\end{tabular}

These species of crustaceans are the first intermediate hosts for $L$. intestinalis. In their body cavity, coracidia develops to the next stage - procercoid. Again by food, the crustaceans with the procercoids developed in them enter the digestive system of the fish from the family Cyprinidae, where the procercoids develop to the next stage - plerocercoid. The carp fish, in this case, is the second intermediate host. In them, the plerocercoids reach an invasive stage for 12-14 months. Fish-eating birds by consuming such fish become the ultimate hosts for the parasite. In the intestines of birds, plerocercoids reach sexual maturity in 3-5 days. The sexually mature cestodes lay eggs for 2-5 days, after which they die and are thrown out (Bauer, 1987; Kakacheva-Avramova, 1983).

\section{Component community}

The found helminth species were fixed in five of nine examined specimens, $C$. gibelio. For the two helminth species, prevalence (P\%) and mean intensity (MI) were determined (Table 1). The species $P$. laevis are distinguished by higher mean intensity and prevalence $(\mathrm{MI}=1.34 ; \mathrm{P} \%=33.34)$ than these of L. intestinalis $(\mathrm{MI}=1.00 ; \mathrm{P} \%=22.23)$. Both species are core species for the helminth communities of $C$. gibelio from the Panicheri Reservoir. They are generalists for the helminth communities of the Prussian carp from the examined freshwater ecosystem.

\section{Infracommunity}

More specimens of $C$. gibelio were infested with the acanthocephalans $P$. laevis (3 specimens of $C$. gibelio). As a result, the Brillouin diversity index is low $(\mathrm{HB}=0.49)$ due to the small number of species and the low mean intensity of the populations (Table 2).

Table 2. Infracommunity data

\begin{tabular}{|l|l|l|}
\hline \multicolumn{3}{|c|}{ Number of helminth species } \\
\hline Number of infected fish & 2 & 3 \\
\hline Number of helminth species & 1 & 1 \\
\hline \multicolumn{2}{|c|}{ Number of helminth specimens } \\
\hline Total number of specimens & 6 \\
\hline Mean \pm SD & $1,2 \pm 0,45$ \\
\hline Range & $1-2$ \\
\hline Mean HB \pm SD & $0,49 \pm 0,19$ \\
\hline
\end{tabular}

\section{DISCUSSION}

The parasitised fish have been found to stop feeding and lose weight due to the dysfunction of internal organs. Cases of gonad degeneration have also been reported. In this disease, a complete atrophy of the fish and death has been reported. The diseased fish become 
very easy food for fish-eating birds because they usually float on the water's surface. P. laevis is an autochthonic species for the parasitic communities of the $C$. gibelio. $P$. laevis develops as a marita in the intestines of some fish species from Cyprinidae, Salmonidae, Percidae, Siluridae and others. The development cycle is associated with the participation of an intermediate host crustaceans of the species Gammarus pulex (Linnaeus, 1758). G. pulex is a bioindicator of $\mathrm{x}-\beta$-mesosaprobia and refers to the relatively tolerant forms (Group C) for environmental conditions in habitats. The higher rates of $P$. laevis invasion are probably due to the higher population mean intensity and the higher prevalence of G. pulex in the studied habitats of the reservoir ecosystem as a relatively tolerant and more plastic bioindicator species and an intermediate host of $P$. laevis. Small fish species of the Cyprinidae have also been identified as reservoir hosts. The species was reported by $C$. gibbelio in Bulgaria (Bauer, 1987; KakachevaAvramova, 1983).

The presented cycles of development of the identified types of parasites testify to the following pathways of circulation of the parasitic flow:

A. In cestodes:

1. Crustaceans - Fish (Ligula intestinalis, larvae) - Birds.

B. In acanthocephalans:

1. Crustaceans - Fish - Fish (Pomphorhynchus laevis, marita).

Five species of endohelminths have been identified for the fauna of $C$. gibelio in Bulgaria (Table 3). Of these, only P. laevis was found in the study. The list of helminths after this study was supplemented by one more species, $L$. intestinalis.

Table 3. Endohelminths of Carassius gibelio from the freshwater ecosystems of Bulgaria

\begin{tabular}{|c|c|c|}
\hline Species diversity & Authors & $\begin{array}{l}\text { Freshwater ecosystems } \\
\text { (Biotopes) }\end{array}$ \\
\hline \multicolumn{3}{|c|}{ Acanthocephala } \\
\hline \multirow[t]{5}{*}{$\begin{array}{l}\text { Pomphorhynchus laevis } \\
\text { (Müller, 1776) }\end{array}$} & Margaritov, 1966 & $\begin{array}{l}\text { river Danube (estuary of the river } \\
\text { Timok) }\end{array}$ \\
\hline & $\begin{array}{l}\text { Kakacheva-Avramova, } \\
1977\end{array}$ & $\begin{array}{l}\text { river Danube (near town } \\
\text { Svishov) }\end{array}$ \\
\hline & $\begin{array}{l}\text { Kakacheva, Margaritov, } \\
\text { Grupcheva, } 1978\end{array}$ & river Danube \\
\hline & Grupcheva, Nedeva, 1999 & reservoir Zhrebchevo \\
\hline & Atanasov, 2012 & $\begin{array}{l}\text { river Danube (v. Archar, v. Dobri } \\
\text { dol, t. Svishov, v. Botevo, v. } \\
\text { Gomotarci, v. Vardim, v. Novo } \\
\text { selo, v. Simeonovo, t. Kozloduj) }\end{array}$ \\
\hline \multirow[t]{3}{*}{ Acanthocephalus anguillae } & Shukerova, 2010 & lake Srebarna \\
\hline & Atanasov, 2012 & $\begin{array}{l}\text { river Danube (villages Archar, } \\
\text { Vardim; town Svishov) }\end{array}$ \\
\hline & Chunchukova, Kirin, 2021 & river Tindja (city Yambol) \\
\hline \multicolumn{3}{|c|}{ Nematoda } \\
\hline \multirow{2}{*}{$\begin{array}{l}\text { Contracaecum } \\
\text { microcephalum }\end{array}$} & Shukerova, 2005 & \multirow[t]{2}{*}{ lake Srebarna } \\
\hline & Shukerova, 2010 & \\
\hline \multirow[t]{2}{*}{ Raphidascaris acus } & Shukerova, 2005 & \multirow[t]{2}{*}{ lake Srebarna } \\
\hline & Shukerova, 2010 & \\
\hline Spirorchis contortus & Shukerova, 2010 & lake Srebarna \\
\hline
\end{tabular}


The Panicheri Reservoir is a new habitat in Bulgaria of L. intestinalis and P. laevis as helminths of $C$. gibelio. C. gibelio is a new host recorded for L. intestinalis in Bulgaria.

\section{CONCLUSION}

As a result of the study of 9 specimens of C. gibelio from the Panicheri Reservoir, Aegean Water Basin, South Central Bulgaria, an infection with two species of endohelminths was found. They are the main species in the helminth communities of the Prussian carp from the studied freshwater ecosystem. The Panicheri Reservoir is a new habitat for both species, and the Prussian carp is a new host for L. intestinalis in Bulgaria.

\section{REFERENCES}

Atanasov, G. (2012). Fauna, morphology and biologyonthe endohelminths of fish from Bulgarian part oftheDanube River. $\mathrm{PhD}$ Thesis, Sofia (in Bulgarian).

Bauer, O. (Ed.) (1987). Key to theParasites of Freshwater Fishes of the USSR. Leningrad, RU: Nauka (inRussian).

Bush, A., Lafferty, K., Lotz, J., \& Shostak, A. (1997).Parasitology meets ecology on its own terms. Journalof Parasitology, 83, 575-583.

Cakis, P., Stojanovski, S., Kataranovski, D., \&Fister, S. (2001). The first findings of the nematode Philometroides cyprini (Ishii, 1931) on Carassius auratus gibelio from the Danube River, Yugoslavia. In: Proceedings of the scientific meeting "Tissue Helminthoses of Men and Animals", Belgrade, 65-70.

CITES, UNEP-WCMC (2020). The Checklist of CITES Species Website. Appendices I, II and III valid from 28 August 2020. CITES Secretariat, Geneva, Switzerland. Compiled by UNEPWCMC, Cambridge, UK. https://www.cites.org/eng/app/appendic es.php [Accessed 4 January 2020].

Chunchukova, M., \& Kirin, D. (2021).Structure of the population of Acanthocephalus anguillae in Carassius gibelio from Tundja River, Bulgaria.Scientific Papers Series D. Animal Science (in press).

Convention on the Conservation of Migratory Species of Wild Animals (CMS)(2015). Appendices I and II of the Convention on the Conservation of Migratory Species of Wild Animals (CMS). http://www.cms.int/en/species [Accessed 12/10/2017].

Froese, R.,\& Pauly, D.(Editors) (2021). FishBase.World Wide Web electronic publication.www.fishbase.org, version (06/2021).

Georgiev, B., Biserkov, V., \&Genov, T. (1986). In toto staining method for cestodes with iron acetocarmine. Helminthologia, 23, 279-281.

Golemanski, V. (Ed-in-Chief) (2011). Red Data Book ofthe Republic of Bulgaria. Sofia, BG: Joint edited of the Bulg.Acad of Sci. and Ministry of Environment andWaters, Vol. 2. - Animalia (In Bulgarian).

Grupcheva, G., \& Nedeva, I. (1999).Parasite fauna of the crucian carp (Carassius auratus gibelioBloch.) in the Zrebchevo reservoir (Bilgaria). Acta zoological bulgarica, 51(1), 115-122.

Djikanovic, V., Paunovic, M., Nicolic, V., Simonovic, P., \&Cakic, P. (2011). Parasitophauna of freshwater fishes in the Serbian open waters: a checklist of parasites of freshwater fishes in Serbian open waters. Rev Fish Biol Fisheries. Doi 10.1007/s11160-011-9226-6

Innal, D., Stavresku-Bedivan, M., Özturk, M., \&Özmen, Ö. (2020). First record of Contracaecum rudolphii Hartwich, 1964 in Carassius gibelio (Bloch, 1782) from Turkey.Aquatic Sciences and Engineering, 35(1), 1-5.

IUCN, 2020. The IUCN Red List of Threatened 
Species. Version 2020-2. . Downloaded 16 July 2020.

Kakacheva-Avramova, D. (1977). Investigation of fishhelminthes from Bulgarian Danube River section.Helminthologia, 3, 20-43 (in Bulgarian).

Kakacheva-Avramova, D., Margaritov, N., \&Grupcheva,G. (1978). Fishparasites of Bulgarian part of theDanube River. Limnology of Bulgarian part of theDanube River, 250-271 (inBulgarian).

Kakacheva-Avramova, D. (1983). Helminths of freshwaterfishes in Bulgaria. Sofia, BG: Bul. Acad. Sci. (inBulgarian).

Karapetkova, M. \& Zhivkov, M. (2006). Fishes in Bulgaria. Sofia, BG: GeaLibris (in Bulgarian).

Kennedy, C. (1997). Freshwater fish parasites andenvironmental quality, an overview and caution.Parasitologia, 39, 249-254.

Kottelat, M., \& Freyhof, J. (2007).Handbook of European freshwater fishes. Berlin, DE: Kottelat, Cornol and Freyhof. (Ref. 59043)

Kucher, H., Stock, T. M., \&Das, M. K. (2019). Parasites of Prussian carp (Carassius gibelio): an invasive species in Alberta, Canada. Canadian J of Zoology, 97(9), 755-762. https://doi.org/10.1139/cjz2019-0021

Magurran, A. (1988). Ecological diversity and its measurement.London, UK: Cambridge University Press.

Margaritov, N. (1966). Helminths of the digestive systemsand the body cavity of the fish from theBulgarian section of the Danube River. Notificationsfrom the Zool. Ins. Museum, XX, 157-173 (InBulgarian).

Petrochenko, V. (1956). Acanthocephalus domestic andwild animals. Moskow, RU: AN USSR (in Russian).

Roohi, D., Sattari, M., Nezamabadi, H., \&Ghorbanpour, N.(2014).Iranian $J$ of Fisheries Sciences, 13(2), 276-288.
http://aquaticcommons.org/22686/1/IF RO-v13n2p276-en.pdf

Selbach, Ch., Soldánová, M., Feld, Ch., Kostadinova, A., \& Sures, B. (2020). Hidden parasite diversity in aEuropean freshwater system. Scientific Reports, 10:2694.

https://doi.org/10.1038/s41598-02059548-5

Shukerova, S., (2005).Helminth fauna of the Prussian carp, Carassius gibelius (Bloch, 1782), from the Srebarna Biosphere Reserve. Trakia J. of Sciences, 3(6):36-40.

Shukerova, S. (2010). Helminths and helminth communities of fishes from Biosphere Reserve Srebarna.PhD Thesis, Plovdiv (in Bulgarian).

Statsoft Inc. (2011) (n.d.). STATISTICA, version 10.Retrieved from www.statsoft.com.

Zashev, G., \&Margaritov, N. (1966).Diseases of fish.Sofia, BG: Naukaiizkustvo (in Bulgarian). 